\title{
Erin Honeycutt*
}

University of Iceland in Reykjavik

\section{DIMENSIONS VARIABLE: TEMPORAL AESTHETICS AND THE WORK OF PIERRE HUYGHE}

\begin{abstract}
In the framework of curator Nicholas Bourriaud's radicant aesthetics, this essay explores the artwork of Pierre Huyghe who uses time as both his subject and his medium in practices of world-making and journeying to express the complexity of unique experiences of the temporal. Huyghe's works play on the subject's dual role in both the creation and inhabiting of a world image, and the way that trajectories of time make their various effects within it. From Benjamin's dialectical image to Kant's metaphysical aesthetics, the complexities of perceiving time and time-based encounters in art are analyzed.
\end{abstract}

Keywords: Pierre Huyghe, time in aesthetics, world-making, metaphysics, contemporary art, dialectics

\section{INTRODUCTION}

The subjectivity of time has been extensively discussed in philosophy. As a human conceptualization of natural rhythms on earth and in space, the subjective perception of elapsed time is further compelled by differences in individual and cultural experience. In modern western society, time is generally perceived as teleological, progressing towards the end of a continuum. However, it can also be said that time is subject to one's cultural environment. Time in the Hindu tradition, for example, is perceived as possessing a cyclical nature, embracing the dissolution and reincarnation of matter. The notion of time may also be considered as an a priori concept, as will be further discussed in terms of Kant's transcendental and metaphysical aesthetics.

It is almost impossible to discuss the aesthetics of time without inherently discussing the aesthetics of space. When considering architecture, for example, it is difficult to experience a built structure without it affecting ones perception of time. Standing at the foot of a skyscraper draws ones focus towards the verticality and upward-motion of the structure, of which, along with the stairwells, elevators, and hallways, the motion is always forward. The skyscraper in this sense is a landmark of teleological thinking where everything is oriented towards continuing on an upward and onward course of time. This dominant structure underpins a social ideology of progress.

* Corresponding author: Erin Honeycutt, University of Iceland, Melhagi 13, 107 Reykjavik; e-mail: ttucyenoh@ gmail.com. 
In other art forms such as film, the mediums' ability to shape reality cannot be underestimated. As one of the plastic arts, film creates reproductions of material phenomena over an elapsed period of time. This essentially has the effect of exploding time using a myriad of effects and tactics such as slow motion which dilates the present moment on screen. Other editing tactics undermine visual and temporal perception as well, such as acceleration, the vertigo effect, and screen montage.

According to the French film scholar Gilles Deleuze, film technique went through a huge transformation after World War II. This happened as a response to the increasing industrialization of consumer capitalism and the goal-oriented excessiveness attached to the technological revolution. This led to the production of time as an image itself, rather than images expressed in real-time, which was now technologically conceivable as well as being a phenomena worthy of exploration in this increasing fluxuation and transportaiton of people in places. However, the image of time is not confined to one lens strategy or array of camera affects, but rather to the reflexive nature of the temporal medium through which the image is being conveyed to the viewer.

\section{NICHOLAS BOURRIAUD AND RADICANT AESTHETICS}

A good starting place for a general overview of temporality in art is in the writings of the French art critic and curator, Nicholas Bourriaud. In his 2009 book, The Radicant Bourriaud describes radicant aesthetics as the intertwining of space and time which turns time into territory. By spatializing time, contemporary art which adheres to a radicant aesthetic produces forms that capture the experience of a territory through practices that are time-specific as opposed to site-specific. Bourriaud also describes time as becoming a topology in this sense. This will be the main point of departure for an exploration of temporal aesthetics in the work of Pierre Huyghe.

One way that this time-specific quality has been expressed is in the journey-form. Even though it expresses a path, the journey as art puts linearity in crisis by injecting time into space and space into time. Bourriaud puts this crisis in a historical context by describing modernism as an ideology in which the past represented tradition that was destined to be taken over by the new (Bourriaud 2009). Postmodernism therefore was when historical time took the form of an archive or catalogue. Today the past is defined by territory, similar to the way in which when one travels it is often to change time periods in the way that anthropology projects time onto space and space into time (Bourriaud 2009).

Another way that this time-specific quality has been expressed, especially in the work of Pierre Huyghe, is in the practice of world-making. Whenever new models of reality challenge human consciousness, an outlying structure affects reason and perception, causing a split in linearity and an encounter with a new terrain of time (Hinojosa). The terrain of time of the present day is best encapsulated in the descriptions of the 'liquid modern society' that started around 1990, according to Bourriaud, and is marked by its cultural precariousness in time and place as the short-lived overtakes the long-term and globalized consumerism creates a constantly shifting environment (Bourriaud 2009). 
Bourriaud's perception of radicant aesthetics is as the art genre continuing from the relational aesthetics of the 1990s. His radicant aesthetics have a great deal to do with the emergence of the internet which created a new context for art and forms of postproduction, as well as globalization. In 2009 , he created the term 'altermodern' to define the new modernity emerging which was more related to art in the context of globalization, while not completely adhering to either modernism or postmodernism.

For Bourriaud, globalization creates a standardization in the same way that multiculturalism creates a decolonizing effect. What this means for the contemporary art world is that the artistic discourse has become heterogeneous but at the same time deriving from non-western visual cultures and both creating a global culture (Bourriaud 2009). It is therefore the specifically western consideration of 'modernity' that needs a reconstruction in favor of a more global modernity based on the concerns of being in the present such as experimentation, the relativity of things, and the 'liquidity' of society (Bourriaud 2009).

Bourriaud's politically minded statement of the emergence of an 'altermodernity' involves reducing the tendency of social and cultural standards to be based in terms of western normality, and especially the embrace of the nomadic movement of a large amount of the world's population (Bourriaud 2009). His argument is that cultural identity should be based more on the often peripatetic nature of life in the early $20^{\text {th }}$ century, rather than on ethnicity and place of origin (Bourriaud 2009).

In Architecture and the Visual Arts, Giuliana Bruno discusses the extent to which the science fiction film Bladerunner is an expression of the tropes of the postmodern condition. The alien replicants in the movie lack an historical origin from which to trace their human existence and for that they must be killed. In exploring the link between temporality in contemporary art theories and temporalities suggested by science fiction worlds, one can see them both as a platform from which to grasp new worlds, and also as a way to elaborate on how the imaginative process of world-making allows one to strengthen the perceptual tools involved in analyzing different temporalities.

One could also consider these 'worlds' as being 'conditions', as did the author, Phillip K. Dick. In order to confront a present 'condition', one must work out the frictions that exist between being-in-the-world and the miasma that is fantasy and illusion (Barikin 2013). Phillip K. Dick is also the author of the popular short story by from which the movie Bladerunner is based, Do Androids Dream of Electric Sheep? This type of question expresses one of the foundations of world-making: cognitive estrangement. According to Barikin, this is the ability to "render thought itself strange, revealing the fragility of perception in the making of meaning" (2013: 11).

So it is primarily the art practices of the journey-form and the world-making form that Bourriaud finds to be expressive of a Radicant aesthetic, each expressing a unique experience of the temporal. The journey-form topologizes time, while world-making creates a new time code, or in some cases sets itself outside of time. There are many artists adhering to this aesthetic, including Pierre Huyghe, and others who have been included in exhibitions for which Bourriaud has been curator. 


\section{KANT'S METAPHYSICAL AND TRANSCENDENTAL AESTHETICS}

One could also approach the aesthetics of time from a Kantian perspective as his transcendental aesthetics applied to time and his metaphysical aesthetics applied to space. Kant established these arguments in his Critique of Pure Reason concerning the nature of time. His goal was to demonstrate that time is an a priori sense in consciousness which structures the cognitive knowing of objects based on their appearance (Hsieh 2004). Kant theorizes that time possesses both "empirical reality" as well as "transcendental ideality," highlighting the principle throughout his arguments for time being an a priori representation as well as the assertion that time itself, not its representation, is a necessary component of the experience of time (Kant 1998).

The status of art is raised to an epistemic level by Kant because his theory of reflective judgement contributes to aesthetics a cognitive effect brought forth by reasoning that purposiveness reflects the capacity of our senses themselves to make determinative judgements. While Kant's ideas are crucial to aesthetics because it places within aesthetics the relationship between the world and our concepts of it, Kant's ideas of knowledge are controversial precisely because of his placement of reflective judgment in the creation of knowledge. In the field of artistic research, Kant's philosophy is beneficial in showing how the production of knowledge and the production of art overlap by describing how concepts play such an important role in the perception of art (Cazeaux 2002). In fact, for Kant, art is a wholly conceptual process since experience is informed both by reflective and determinative judgements. It is in the reflective use of concepts that Kant puts art at an epistemic level.

Kant's theories of judgment are also beneficial because they present artistic practice as knowledge by situating metaphorical concepts as a foundational processesing mechanism that we employ to understand the world. From there, metaphor helps to generate the conceptual relationships required to generate a structure of knowledge. Kant's defining of aesthetic judgement as the viewer's perception of work in relation to conceptually relating between it and its significance to the outside world allows further aesthetic judgements to be made, the epistemic value of which lies in its relationship to the artwork (Cazeaux 2002). What Kant's aesthetic theory shows is that the residual opposition between theory and practice has to be lifted since the concepts which are explored in theory are the same concepts which allow for the artist and viewers of their artwork to perceive with purposiveness (Cazeaux 2002).

The ruling point in the aesthetic knowledge of art would seemingly bear upon the shape of its form, which comes in a multitude of varieties, some being more blatantly physical, or physically integrated, than others. It is widely assumed that conceptual art is anti-aesthetic by nature which shows how the millenia old argument between empiricism and romanticism is still ongoing. It also shows, despite transforming the classifications of what is and is not a form of art, how traditional the conception of form is when regarding conceptual art. As well, it shows how conclusive an assumption it is to regard the aesthetic dimension of art as a response to its visual qualities, without regarding the ideas these qualities convey (Costello 2007).

The physical form of the concept relays their effect, which according to Kant, would be the same as if one were reading a description or imagining the experience of it, rather than 
experiencing them firsthand (Costello 2007). Although it is still plausible for the concept behind the conceptual artwork to be as strong or weak as the form it takes, the viewer's response is formed significantly in how the concept embodies the meaning (Costello 2007). Conceptual art could be seen as having an ability to meet the viewer 'half-way' in terms of aesthetic reception, or as having the ability to offer an extension of the viewers' senses into the degree of the works' vanishing point, and therefore be a structure built on our aesthetic knowledge.

In some ways, this ability corresponds to Kant's theory of the metaphor as a foundational processing mechanism that we employ to understand the world and from there, metaphor helps to generate the conceptual relationships required to generate a structure of knowledge. In the context of a dematerialization of art, Kant's aesthetics pose certain questions about how aesthetic thought is applied to conceptual and postmodern art, and, as in the work of Pierre Huyghe, to artworks that have no medium themselves. In emphasizing the significance of time in Kant's Critique of Pure Reason, Heidegger played a considerable role in demonstrating how Kant's transcendental object may also be representative of temporality as it establishes a unifying consciousnesswas (Cazeaux 2007). This demonstrates, in part, a new form of Kant's understanding of time as the the pure form of intuition.

Kant's form of 'intuition' acknowledges the constant receptivity of empirical intuition, of the plane of reception of representations upon ones consciousness. This is where Heidegger disbands from Kant in his finding that empirical intuition is not receptivity itself, but productivity: "time... is constitutive of the possibility of receptivity. This is time understood not empirically as a succession of 'nows', but primordially, 'as that which lets time as the now-sequence spring forth"” (Cazeaux 2007). The complexity of perceiving time is very apparent by both philophers. The singularity of each passing, and approaching, present moment puts Kant's intuitive form of knowing time in a continuously extending perception of experience. The "series of representations" that connect time's flow of past, present, to future necessitates a phenomenological approach to categorizing the experience of time, as well as the dialectical nature of time, both of which form major concerns when considering the breadth of temporal aesthetics in terms of art practices (Cazeaux 2007).

\section{PIERRE HUYGHE}

Born in 1962 in Paris, Pierre Huyghe studied at the Ecole Nationale Supérieure des Arts Décoratifs. He lives and works between New York and Paris, experimenting with time-based art and exhibition practices. Huyghe's art is delivered in a wide variety of forms including films and installations with world-making elements. In the 1990's, he and other artists in France at the time made a shift in their art towards creating more fully composed exhibitions, or 'worlds', within the space of the gallery rather than insular art 'pieces'. This came to be known as Relational Aesthetics, as the term was coined by Pierre Bourriaud to whom it became clear how different the role of curator is in such diaphanous, time-based encounters.

At The Artist's Institute in New York City in 1999, Huyghe scraped away at the paint on the exhibition space walls, showing remnants of the exhibitions shown earlier in the program's history. In a way in which one might read the rings of a tree trunk, the layers of 
paint in Timekeeper reverted time, bringing "the anthropological recent past into the present" (Hinjosa). Huyghe uses time as both his subject and his medium. In a complexity of architecture and art, he uses visual effects, performance-like features, and practices of world-making and journeying to explore the temporal in contemporary life.

THE THIRD MEMORY (2000)

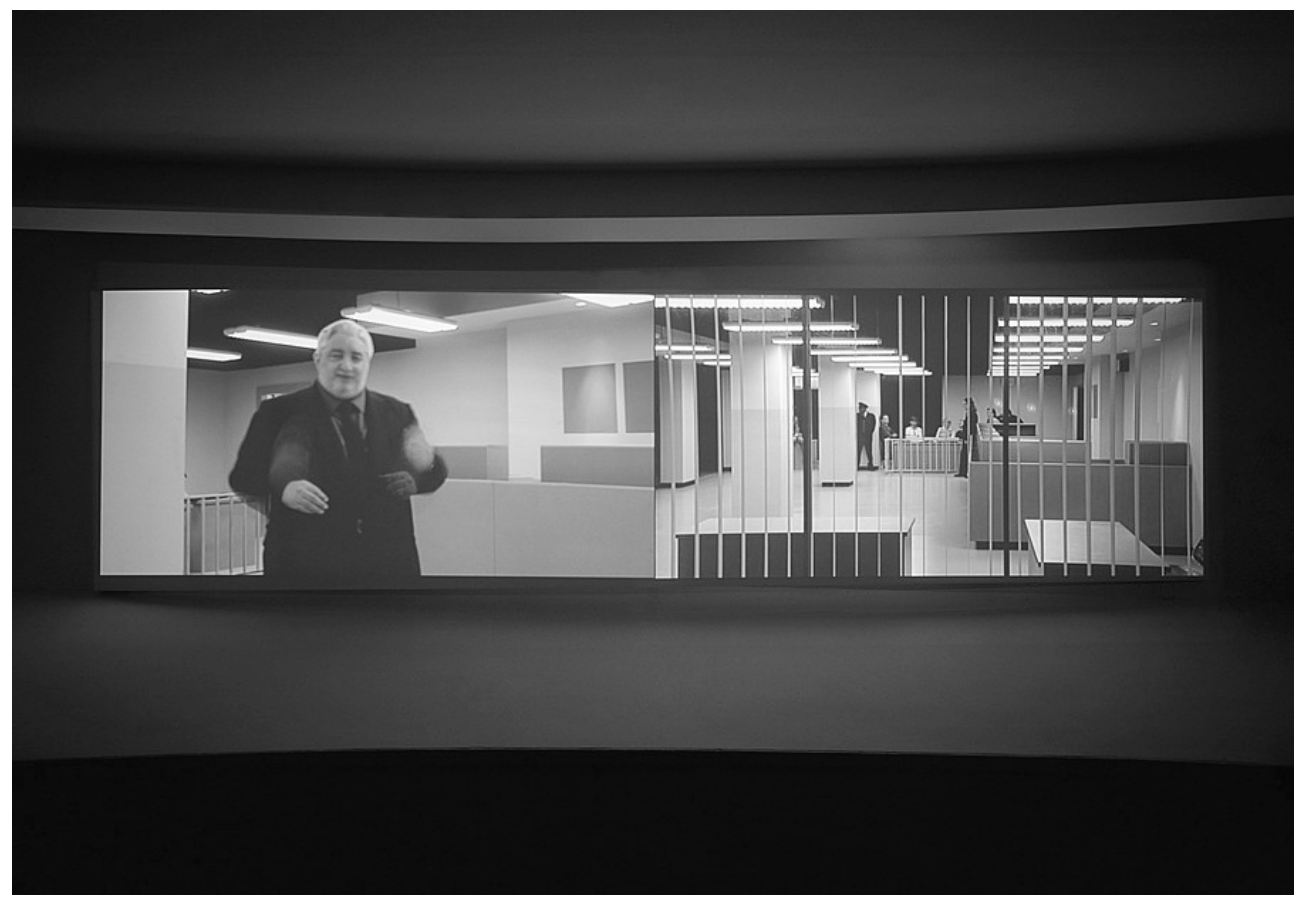

Figure 1. The Third Memory, 2000

Source: Guggenheim.org

In another project, Huyghe's art slips into world-making as the viewer gets a glimpse of the overlaps between what is life and what is media, or what is real and what is representation. In his piece from 2000, The Third Memory (Fig. 1), he takes the film about the true-crime bank robbery in New York City in 1972, Dog Day Afternoon, and instead of starring Al Pacino as the main bank robber he has the actual paroled bank robber tell his story of the real event to an audience (Farago 2014). However, his recollections of the event are so bound with the Hollywood version of the event that one can see how the media has created a third memory of the event. Interestingly, the real paroled bank robber, John Wojtowicz, went to see Al Pacino in The Godfather to get inspiration for his own bank robbery that same day. Huyghe uses scenes from Hollywood cinema in other works as well, as a malleable medium with which 
to make inquiries into the effects of mass media on cultural memory, and the extent to which media and art imitate one another.

\section{LES PASSAGERS (THE PASSENGERS, 1996)}

In a previous work from 1996 called Les Passagers, Huyghe offers an open invitation to visitors of the art museum to go on a bus tour from Bordeaux with Huyghe as their guide. Along the route, passengers watched pre-recorded footage of the same exact route on a monitor screen in the bus. As passengers travelled through the landscape, the journey was deflected through the two screenings, one through the bus window offering the journey in real time, and one through the monitor, offering the journey in time past. This double formatted delivering of time is Huyghe's way of revealing the modern inability to be inside the present moment, and also offering an understanding of how to inhabit the now, and even a way of asking the viewer how they want the present to be told to them.

\section{UNTILLED (2012)}

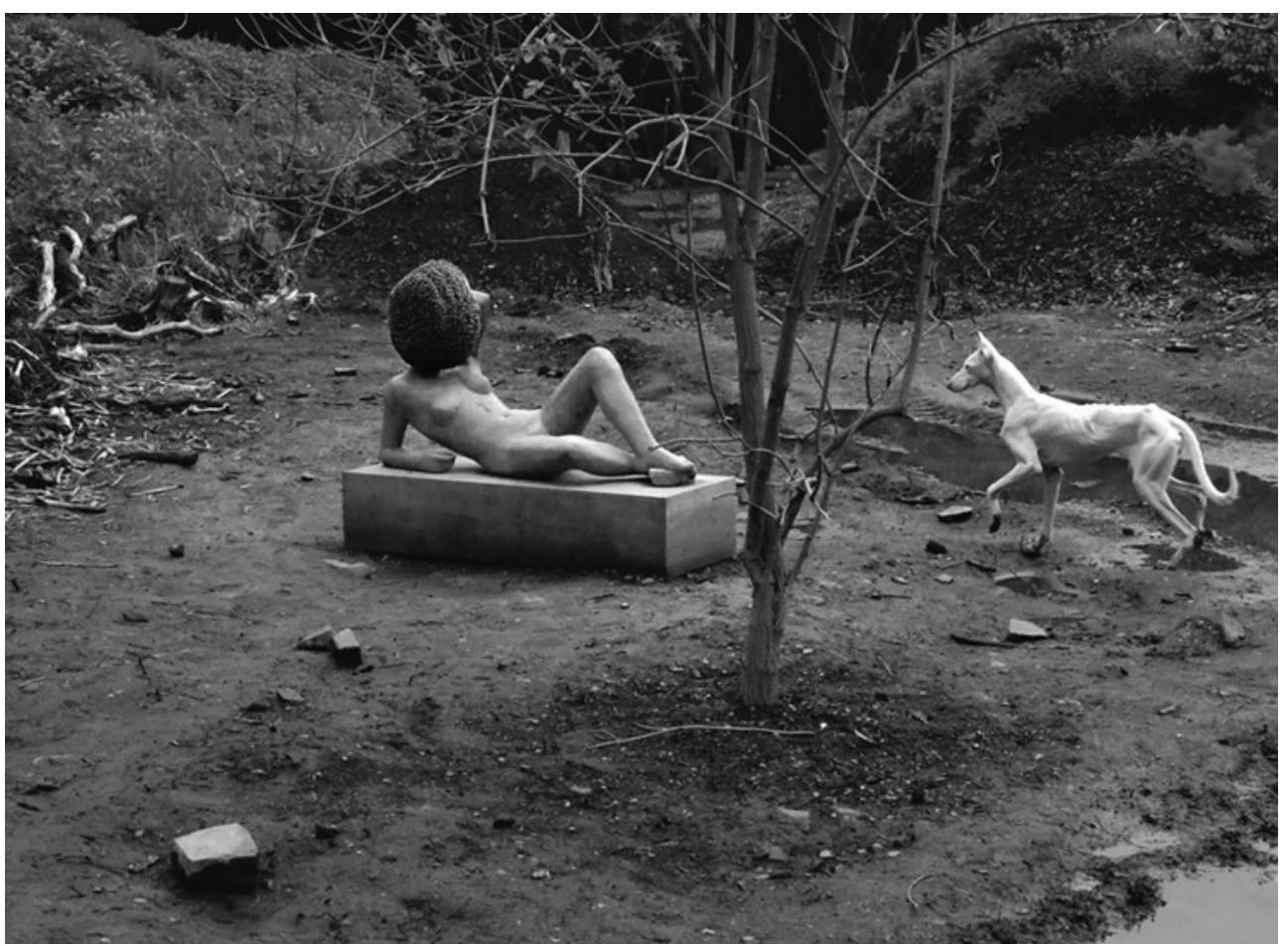

Figure 2. Untilled (2012), Documenta 13; Kassel

Photo by Stephanie Keenan, LA Weekly 
Huyghe created Untilled (Fig. 2) for Documenta 13 in Kassel's Karlsruhe Park. In the work, an encounter is created between natural elements and human-made elements at a compost site, producing an environment in which both elements stood on equal terms. The artist's Ibizan Hound, Human, with a front leg dyed pink with food coloring, roamed the site like an apparition, although one with the free-reigning regality of the exhibition's elusive focal point. A reclining nude female sculpture with a hive of bees covering the head lay isolated in a coven of stone slabs. Also included in the site are psychotropic plants tucked amongst imported trees, earth, rocks, concrete blocks, water containers, turtles, ants, and tadpoles (Barikin 2013). The effect created is otherworldly, or as though you have stepped into one slice of a world belonging to a different reality. One could say that the practice of world-making is based on the sense that there is no singular form of the world, as it has been pluralized by globalization and in a sense, destroyed (Barikin 2013).

The presence and wanderings of the Ibizan hound, Human, takes precedence in Huyghe's film of the site, A Way in Untilled (2012). Using a contrasting array of light and weather conditions along with the use of the camera's abilities to explore at micro and macro scales in the environment, a lost sense of time and place is created (Saunders 2014). Zooming into terrestrial life, while offering wide screen shots of the stones and slabs of the built environment, Human is followed as the main protagonist in Huyghe's forage into aesthetic boundary emission and collapsed storyline, although nonetheless suspenseful (Saunders 2014).

\section{THE HOST AND THE CLOUD (2010)}

In Huyghe's year-long experiment, a young woman is hypnotized into a trance state by a professional. She murmurs pieces of information leading us to know something of death and rabbits as she lies with eyes closed, speaking in bursts and pauses. She is composed in an awkward position, hair covering her face and arms across her chest. In the second part of the experiment, the visitor watches as the same woman listens to the recorded session of her trance in the empty cinema of an abandoned museum, the former Musée National des Arts et Traditions Populaires in Paris. This is her first time hearing her own words spoken in such an altered state and she is transfixed by it. Adding to the dreamlike atmosphere of the scene is a red cloud of smoke along with the dark and lingering sound of an Angelo Badalementi track.

Hand puppets begin to act out the scene on the cinema screen. The characters of the patient and the hypnotist discuss her trance state in a shadow play. Meanwhile, the patient sits alone watching in the empty cinema and begins to cry as she is overcome with these irreconcilable parts of herself (Barikin 2013). According to Amelia Barikin, Huyghe's works are composed of agents such as puppetry, hypnotism, and psychotropics, which share a common infliction: they have been in contact with an alternative realm of time (Barikin 2013). Ones sense of subjective self is contingent on ones sense of time. In this way, being confronted with a foreign chronology disrupts the singularity of ones subjective ontology. For a dreamer or person in a trance state, the subject is both host and creator of the dream or hallucination (Barikin 2013). Huyghe plays on the dual agency of the subject's role in both the creation and inhabiting of a world image, and the way that trajectories of time make their various effects within it. 


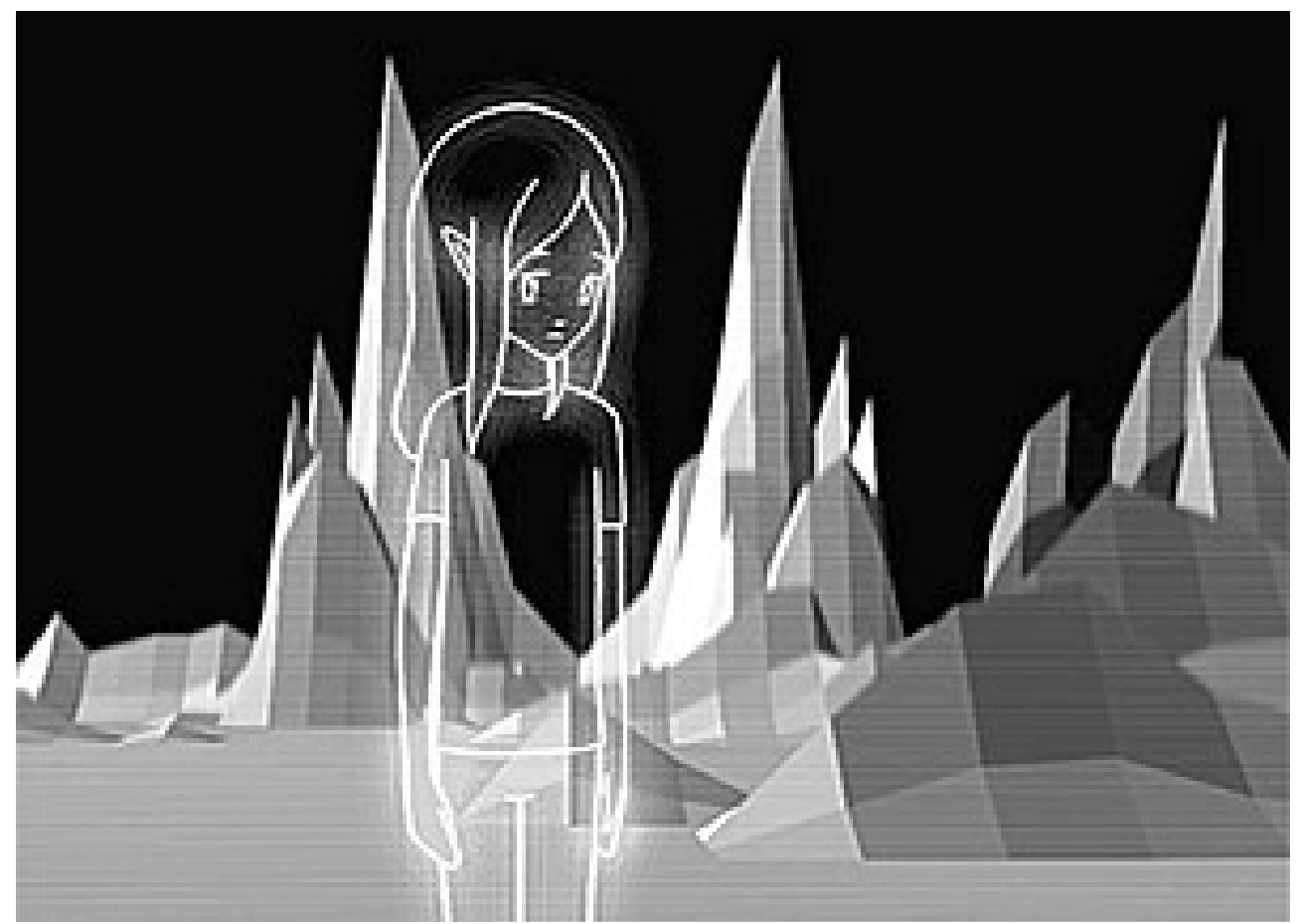

Figure 3. One Million Kingdoms, 2001

Source: Guggenheim.org

In Pierre Huyghe and Phillipe Parreno's collaborative project No Ghost Just a Shell, the temporal aesthetics of time-based arts is inherently tied to the limits and possibilities of its medium. Francis Halsall, in No Medium just a shell: how works of art configure their medium, argues that the work of art gives the medium form, configures it and thus actively constitutes it as a medium (2007). Discussed is Arthur C. Danto's biggest claim that "after the end of art, first aesthetic judgment has ceased to be the guiding principle of art; and second, the making of art is no longer stylistically constrained by historical conditions. Instead pluralism reigns" (Halsall 2007). Danto describes this historical end of a condition of art in terms of postmodernity being the end of using solely perceptual and aesthetic qualities to judge between art and non-art (Halsall 2007).

In No Ghost Just a Shell the artists observe the invisibility of mediums of forms via other mediums. The artists acquired the files and copyright for a basic female character in the Japanese Manga style for \$400. The character's name is Annlee, an anonymous 'avatar' used only for playing in minor roles. A preteen girl with the Manga prototype of wide-set eyes and blue hair being the only distinguishing features. At the Zurich Kunsthalle and the San Francisco MOMA in 2002 and 2003, Huyghe and Parreno commissioned twelve works from 
a variety of artists consisting of an equally wide variety of mediums: animations, paintings, posters, books, neon works and sculptures.

In this way, Annlee became the 'shell' for a variety of different manifestations and the medium for those manifestations as well. For example, Rirkrit Tiravanija's Untitled (Even Electric Sheep Can Dream) consists of an eight-hour digital animation in which Annlee reads aloud Philip K. Dick's short story Do Androids Dream of Electric Sheep in its entirety. With each different manifestation of Annlee's form is a new material of which Annlee is made. Therefore, she is not a medium specific but a conglomeration of elements open to a possibility of forms (Halsall 2007). In this way, Annlee is not a ghost but a shell to be filled, a reference to the 1995 Manga film Ghost in the Shell by Mamoru Oshii.

Annlee's existence depends on her as a form, not as a medium. The post-medium practice of No Ghost Just a Shell does not quantify a specific medium but rather a set of possibilities within a variety of forms. This corresponds to the end of art history because Annlee does not follow a historical precedent in which she is recognized, unlike a painting or sculpture (Halsall 2007). Being unconstrained from historical precedent by choice of medium frees the work that the artist does. This is just another example of an aspect of temporal aesthetics related to medium and historicity.

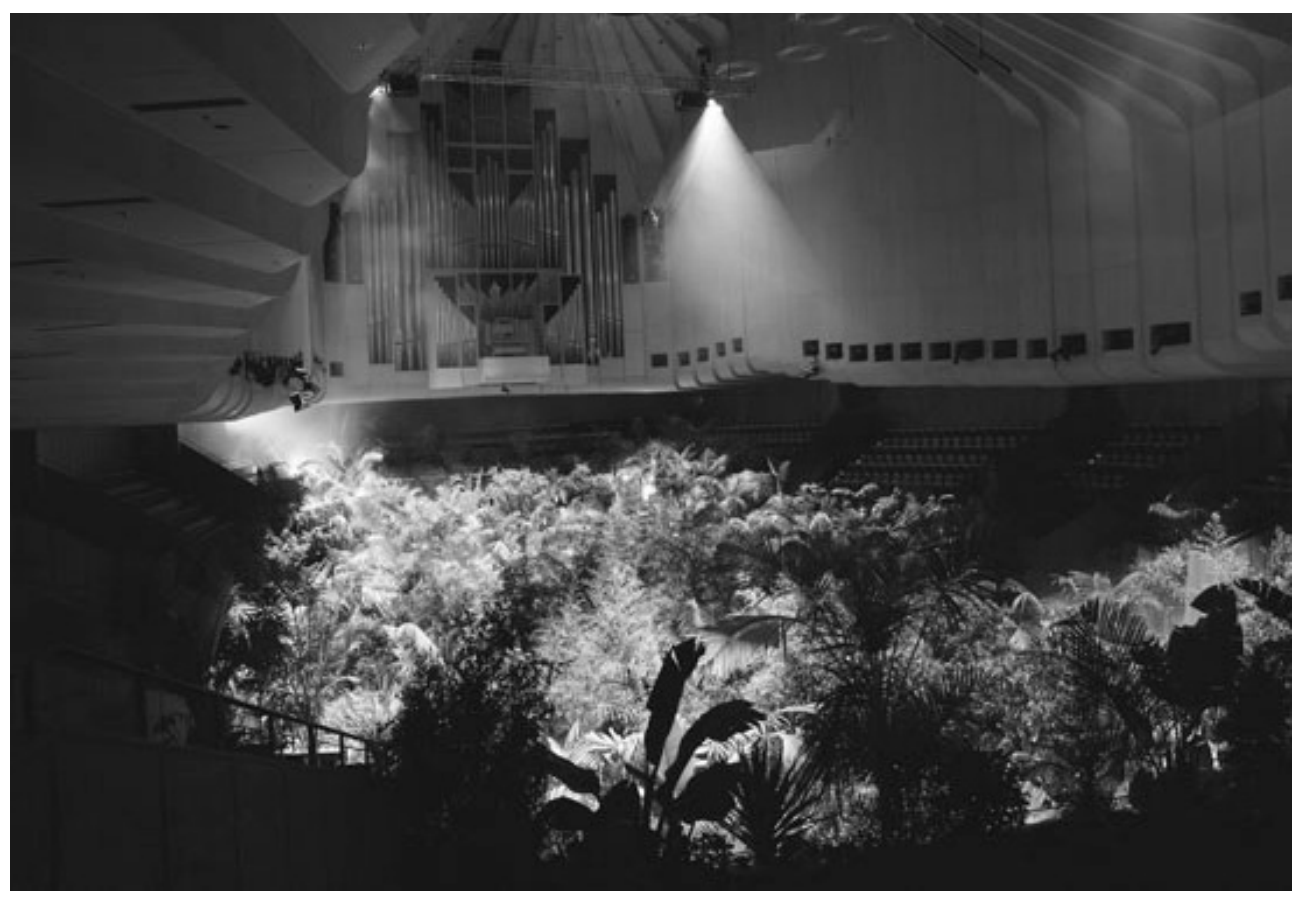

Figure 4. A Forest of Lines, 2008

Source: Biennale of Sydney 
In the Summer of 2008, at the Sydney Opera House concert hall, Huyghe created a dreamlike ecosystem within the building. With clouds and mist obscuring the tree canopy where the orchestra pit would be, intersecting lines of light cross through the densely built environment of the auditorium. The lines of light are coming from the headlamps worn by visitors as they explore the dark forest floor. The whole scene is swathed in the barely audible voice singing overhead. The lyrics are made up of directions for the visitors to make their exit from the building, but not just away from the exhibition. The lyrics' directions sing as well about how to get over the Sydney Harbor Bridge, up the overlapping highways leading into the city, and directly towards the ancient rainforests that lie in the vast landscape of Northern Australia (Barikin 2013).

Huyghe describes the song as being a translation of the context of the image that the journey-form creates (Barikin 2013). The condition of the journey as an intended event, and not as a concretized event, has the effect of creating a "time outside of time and to magnify the opaque materiality of an alternate present" (Barikin 2013). The exhibition in the Sydney Opera House only took place in a twenty-four hour window, or a single rotation of the earth. As the forest appeared and then disappeared, the experimental nature of representation of place transformed into an otherworldly environment. The dense jungle setting created a crystallization of time's fragmentary nature. In the forest, all of time is at once occurring and recurring in a time parallel to Huyghe's freed time. Time is returned to its all-encompassing current, a backdrop to the living moment (Barikin 2013). Our role as viewer is as producer of events, not only subjects, co-creating the present with our consciousness.

\section{THE TIME OF ART AND PHENOMENOLOGY}

The sense of time in Pierre Huyghe's work is phenomenological as these temporal conditions are based on sense experience. This process is a reminder of the double act of the viewer in being at once both creator and inhabitor in an image of the world, a process which Huyghe has aptly described as a 'third memory', or "the displacement of an event onto its representation so as to create an entirely new object of translation" (Barikin 2013). One could visualize Huyghe's representations of temporality in the form of landscapes as world-making often begins in the conceptualization of landscape.

With landscape, in the viewing and the creating of it, there already is a dislodging of the paradigm between the eye, the mind, and the image because ones body has to be somewhere physically to engage in landscape. Seeing means to see from somewhere. Landscape in particular asks the viewer and creator to consider how they orient themselves to being present. In a landscape, this invariant of structure is the horizon line, and that is the constant from which we can abstract from the world.

Another way to consider a temporal aesthetic is to consider the time of art. It is not comparable to the time of the museum's opening hours, or the duration of a film, or the time it takes to get from one place to another, although it can contain all of these elements. The time of art is basically phenomenological, as related to the sensed experience of an art work in space over time. The relationship of art to time is shown more and more often in contemporary 
works in the form of temporary projects, in situations without end, and in relationship between events, and it mirrors the way time is actually presented in everyday life.

\section{WALTER BENJAMIN'S DIALECTICAL IMAGE}

Walter Benjamin was interested in this unknown side of reality that was appearing in the light of the present, most notably in the form of photographs and film. It is not what what is past that casts its light on what is present, or what is present that casts its light on what is past, rather the image is where what has been comes together in a flash with the now to form what Benjamin calls the dialectical image. This is an image which has two sides: a past and a present, and it gives us in a flash, knowledge on the past and on the present.

Benjamin's description of the aura is as a strange texture of space and time, or the unique appearance of distance. According to him, the development of film and photographs has led to the aura's disappearance. In its place we find the dialectical image. Benjamin tries to show that the decline of the aura is not just some aesthetic question, but that it is connected to the traditional philosophical problem of defining truth and the relation between cultural memory and the rational present.

In Benjamin's claims of the existence of a dialectical image, it is never clearly stated in which realm this image belongs. It is seemingly at once belonging to material reality and virtual reality, as well as existing as a picture and a perception (Auerbach 2007). It is also unclear how to distinguish the hypothetical dialectical image from a metaphor. In Benjamin's magnum opus Arcades Project, or Passagen-werk, he presents "an image in which a construction site seems to merge with a ruin," as described by Anthony Auerbach in his essay Imagine No Metaphors on the dialectical image on Benjamin. When trying to make a clear outline of the nature of the dialectical image, Auerbach notes that the two signs image and narrative mark two distinct possibilities.

Image evokes notions of a diagrammatic analogy that places the dialectical image in a constellation of possibilities, similar to a Venn diagram which can suggest the myriad levels of interaction between overlapping notions involving the dialectical image. Narrative on the other hand, could be described best by the diagram of a genealogy showing the history and evolutionary outcome of that history. "History decays into images, not into stories," is one example of the fragmentary admonition that Benjamin offers in his explanation of the dialectical in regards to the archaeology of the recent past (Auerbach 2007). Most of all, his texts speak to the imagination and the reader's ability to be affected by the magical effects of his metaphorical use of language.

\section{CONCLUSION}

According to Benjamin, the dialectical image only exists in the "now of knowability" in which the past aligns with the future in a state of the present. In his Arcades Project Benjamin states: "[...] image is dialectics at a standstill. For while the relation of the present 
to the past is a purely temporal, continuous one, the relation of what-has-been to the now is dialectical: is not progression but image, suddenly emergent" (99: 462). In a similar application to arts practices, the image of time is not confined to one lens strategy or array of camera affects, but rather to the reflexive nature of the temporal medium through which the image is being conveyed to the viewer. This complexity of perceiving time is well known to Huyghe, whose works play on this dual agency of the subject's role in both the creation and inhabiting of a world image, and the way that trajectories of time make their various effects within it.

\section{REFERENCES}

Auerbach, Anthony. 2007. Imagine No Metaphors: The Dialectical Image of Walter Benjamin, „Image \& Narrative: Online Magazine of the Visual Narrative Issue” 18.

Barikin, Amelia. 2013. Introduction, in: Making Worlds: Art and Science Fiction, ed. Amelia Barikin and Helen Hughes, Melbourne: Surpllus Publishing, pp. 7-13.

Barikin, Amelia. 2013. Memories of the Future: On the Time of Art, transl. Jean-Francois Cornu, in: Emma Lavigne and Pierre Huyghe, Pierre Huyghe, exhibition catalogue, Centre Pompidou: Paris.

Benjamin, Walter. 1999. The Arcades Project, ed. Rolf Tiedmann, transl. Howard Eiland and Kevin McLaughlin, Cambridge, MA and London: Belknap Press/Harvard University Press.

Bourriaud, Nicholas. 2009. The Radicant, New York: Lukas and Sternberg.

Cazeaux, Clive. 2002. Art and Knowledge in Kant's Aesthetics, Working Papers in Art \& Design Volume 2. Hertfordshire: University of Hertfordshire.

Cazeaux, Clive. 2007. Metaphor and Continental Philosophy: From Kant to Derrida, London: Routledge.

Costello, Diarmuid. 2007. Kant After Lewitt: Towards an Aesthetics of Conceptual Art, in: Philosophy and Conceptual Art, ed. Peter Goldie and Elisabeth Schellekens, Oxford: Oxford University Press, pp. 92-116.

Farago, Jason. 2014. Pierre Huyghe at LACMA..., The Guardian, http:/www.theguardian. com/artanddesign/2014/dec/04/pierre-huyghe-lacma-retrospective

Halsall, Francis. 2007. No Medium just a shell: how works of art configure their medium, Journal of Visual Art Practice 5: 45-59.

Hinojosa, Lucia. Pierre Huyghe at The Artist's Institute, New York City, www. gnomemag. com/Pierre-huyghe

Hsieh, Diana Mertz. Kant on Time, Philosophy in Action Radio Blog, www.philosophyinaction.com/docs/kot.pdf

Kant, Immanuel. 1998. Critique of Pure Reason, ed. and transl. P. Gruyer and A.W. Wood. Cambridge: Cambridge University Press.

Saunders, Wade. 2014. Pierre Huyghe at Centre Pompidou, Paris, Art in America, http:// www.artinamericamagazine.com/reviews/pierre-huyghe-/. 


\section{ZMIENNOŚĆ WYMIARÓW: ESTETYKA CZASOWOŚCI ORAZ TWÓRCZOŚĆ PIERRE’A HUYGHE’A}

Odwołując się do estetyki relacyjnej autorstwa Nicholasa Bourriaud, w niniejszym artykule poddano analizie dzieła Pierre'a Huyghe'a, który wykorzystuje czas zarówno jako przedmiot, jak i środek w praktyce tworzenia świata oraz peregrynacji w celu wyrażenia złożoności unikatowego doświadczenia czasowości. Prace Huyghe’a pełnią w tym procesie podwójną funkcję: w tworzeniu i zamieszkiwaniu obrazu świata, a także w trajektoriach czasu kreujących zróżnicowane efekty w ramach tego obrazu. Z uwzględnieniem dialektycznego obrazu W. Benjamina oraz metafizycznej estetyki I. Kanta omówiono zawiłości percepcji czasu oraz konfrontacji dokonujących się w sztuce.

Słowa kluczowe: Pierre Huyghe, czas w estetyce, tworzenie świata, metafizyka, sztuka współczesna, dialektyka 